\title{
Study on the Strategies of Cultivating Cross-border E-commerce to Promote Transformation of Regions Foreign Trade Growth
}

\author{
$\mathrm{Yu} Y \mathrm{u}^{1}$ \\ ${ }^{1}$ Hubei Institute of Science and Technology, Xianning, Hubei, 4370002 \\ 346591653@163.com
}

KEYWORDS: E-commerce; Foreign Trade Growth; Strategy

\begin{abstract}
In recent years, the development of cross-border e-commerce preached gratifying situation, to maintain a steady growth of China's foreign trade plays an important role in promoting. Cross-border e-commerce as a new model of international trade and means to effectively reduce costs, improve efficiency, develop new marketing channels and enhance the international competitiveness of Chinese brands, and actively promote the transformation and upgrading of China's foreign trade. Its rise and its application will bring the entire economy and society brought about profound changes to the foreign trade enterprises to create huge profits, and ultimately bring huge benefits for the national economy. Cross-border e-commerce also exist at the same time a lot of great achievements worth pondering the problem of how the development trend of cross-border e-commerce, cross-border e-commerce on how to influence China's foreign trade, China's cross-border e-commerce development process which still exist problems, which we need to do further research and exploration.
\end{abstract}

\section{Introduction}

"Twelve Five" period, the state will be e-commerce as an important part of the next phase of the information technology industry, the development of e-commerce is the top priority of China's information construction. For such a positive environment, large-scale development of online trade is imperative. For the further development of China's cross-border e-commerce to create a favorable policy environment, promote the stable development of cross-border electricity supplier, the state of cross-border e-commerce services pilot in December 19, 2012 officially launched the first batch of pilot cities of Zhengzhou, Hangzhou, Ningbo, Shanghai, Chongqing, Guangzhou, which indicates that the development of cross-border e-commerce is entering a new phase.

In recent years, the Government has introduced policies to support the development of e-commerce, from standards and supporting the institutional level have introduced laws and regulations, the development of a standardized system, in order to promote sustained and stable development of cross-border e-commerce. From October 1, 2013, China's relevant departments jointly issued the "Opinions on the implementation of cross-border e-commerce retail outlet support of the policy" has been introduced in some areas, a move to the stable development of e-commerce has played a positive promoting effect. July 23, 2014, the General Administration of Customs released the Announcement No. 56, document summarizes the implementation of cross-border e-commerce pilot, he stressed the importance of cross-border e-commerce in China's foreign trade, a clear cross-border electricity to carry out the supervision of the whole idea. In efforts to support 
the government, our country will certainly cross-border e-commerce has made considerable development, thus contributing to the development of China's foreign trade.

\section{Dilemma of Hubei Foreign Trade Growth}

Comparative data nearly five years in Hubei Province and major coastal provinces of Shandong, Jiangsu, Zhejiang, Shanghai, Guangdong and other provinces in terms of total imports and exports and growth can be seen in Hubei total imports and exports, total exports, total imports were significantly behind other coastal provinces and cities, and there is a big gap. But the relatively high growth speed, which shows great potential in Hubei Province, import and export development, dynamic growth, should continue to promote sustained and healthy development of import and export.

From the business point of view, in addition to general trade exports in 2009 to maintain a rapid and stable growth, general trade exports \$ 36.51 billion in 2013, higher than the processing trade exports, showing a decline in exports of processing trade in 2012 and 2013 trend. From the main export commodity type of mechanical and electrical products and high-tech products, the exports of electromechanical products is far greater than the high-tech product exports, except 2009 and 2010, the export of electromechanical products is also greater than the growth rate of high-tech products export growth rate, in 2012, high-tech exports fell even appeared in the case, suggesting that the structure of export products in Hubei Province to be further optimized and adapted.

2014 Hubei Province general trade decreased by 11.51\%, processing trade also fell by 5.9\%, which feed processing trade declined by 7.02\%. Hubei Province in 2014 described a situation occurs exports decline, faced with the plight of foreign trade growth. Hubei Province in 2014 total export value divided by the nature of business statistics show 14.76 percent year on year growth of state-owned enterprises, but private enterprises, private enterprises and individual industrial and commercial households decreased by $25.21 \%$, 25.79\% and $76.18 \%$, market activity decreased, which Hubei problems provincial foreign trade enterprises in the face of the current foreign trade is closely related to, the main problems: a low level of information, order small quantities and fragmentation, decline in product advantages, the lack of core competitiveness of the market. Overall, Hubei development of foreign trade is facing tremendous pressure, outstanding performance in the absence of new growth points of foreign trade and new energy, the industrial structure is relatively backward, can not adapt to today's rapidly changing market environment. Cross-border electricity supplier as a new mode of foreign trade development should become an important way in Hubei province foreign trade development, how to foster cross-border electricity supplier to promote the transformation of foreign trade has become an important issue in Hubei Hubei face.

\section{Foster Cross-Border E-commerce to Promote the Transformation of Foreign Trade Growth in Hubei}

Hubei Provincial Government at all levels should pay full attention to cross-border trade in promoting growth and transformation of the status and role of the development of cross-border electricity supplier as a next step to promote the development of foreign trade, stimulating the export market vitality, to achieve an important means and ways to optimize the trade structure. Governments can through financial support, tax incentives and other measures to encourage enterprises to carry out cross-border electricity supplier business, open up involving all levels of cross-border electricity supplier, to optimize the integration of all aspects of cross-border electricity 
supplier for enterprise business development to provide convenient conditions, in order to attract more cross-border electricity supplier companies stationed in Hubei Province to carry out cross-border electricity supplier business. Hubei cities, regions should be combined with the local industrial structure, to achieve docking with the cross-border electricity supplier, to stimulate new vitality throughout the industry, such as equipment manufacturing industry and the cross-border electricity supplier in Hubei Province to achieve docking and integration, promote equipment manufacturing exports.

Cross-border electricity supplier development depends on good laws and regulations, only the establishment of regulatory systems and regulatory regimes of cross-border electricity supplier in order to give full play to the role of cross-border electricity supplier to promote the development of foreign trade, otherwise it will lead to cross-border electricity supplier market confusion. Through the improvement of relevant laws and regulations of cross-border electricity supplier, appropriate to strengthen the supervision of cross-border electricity supplier, to ensure the safe operation of import and export in a reasonable docking and service platforms. At the same time, through the improvement of cross-border electricity supplier-related laws and regulations, we can unify and integrate cross-border electricity supplier in the province and across the country, providing resources utilization efficiency, the cross-border electricity supplier-related customs, payment platform, logistics network regulate cooperation for the realization of cross-border electricity supplier sustained and healthy development.

Cross-border electricity supplier development is based on Internet technology and logistics network system, and promote the development of cross-border electricity supplier must be synchronized promote the construction of related infrastructure. On the one hand, to promote the construction of information network, to create a good online platform for cross-border electricity supplier operations can be carried out through the construction of information network construction of cross-border electricity supplier incubator park or promotion center, to ensure network security and facilitate cross-border electricity supplier operations, especially in the construction of cross-border electronic business platform payment platform infrastructure aspects to put more effort, in cooperation with the bank, effective supervision and measures to effectively guarantee payment security platform. On the other hand, to promote the logistics network system infrastructure to provide the necessary protection for the cross-border flow of electricity supplier product lines under construction and integration through the harmonization of regional logistics system and infrastructure, increase product storage, transport and other service stations, by increasing road, rail, air transportation infrastructure to expand coverage of the convergence criteria by regulating the transport efficiency of different modes of transport between all levels of city, county, town, village to form a full coverage of the logistics network, to achieve the province's logistics efficient operation.

Hubei Province should fully learn the cross-border electricity supplier in the cross-border pilot provinces experience electricity supplier business model, through visits, visits and other forms of concrete measures for other provinces in terms of the development of cross-border electricity supplier, reasonable comparison in cross-border provinces between different electricity supplier development, grasp the overall trend of cross-border electricity supplier development. Should expand cooperation with other provinces, complementary advantages, enhance the promotion of cross-border electricity supplier, we can carry out cross-border development of electronic business in the form of seminars, etc. and other provinces to strengthen cross-border between different provinces development of electronic business interoperability, Hubei Province as an important access to the sea in Northeast China, leveraging cross-border electricity supplier should create new 
economic growth point, to build an open platform to serve the entire northeast region, to achieve the coastal economy and through cross-border electricity supplier hinterland economic interaction. Strengthen cooperation Another important focus is to strengthen international cooperation, actively participate in international negotiations and cooperation in cross-border electricity supplier-related projects, the establishment of taxation, customs clearance, data sharing cooperation and other cooperation mechanisms, the information platform for enterprises to overseas docking overseas docking positions and logistics network to create favorable conditions.

Hubei Provincial Government at all levels should thoroughly enterprises, especially the majority of SMEs in depth to fully understand the needs of enterprises in the import and export trade, in order to carry out scientific planning and guidance. The main target of cross-border electronic business platform services are the majority of SMEs, only fully understand the needs of SMEs in all aspects in order for each node to optimize cross-border electricity supplier in order to attract more SMEs to participate in cross-border electricity business platform, ensure the vitality of the cross-border electricity supplier development. Cross-border electricity supplier development should be combined with the actual situation of import and export in Hubei Province were some planning guidance, so that cross-border electricity supplier development and industrial structure in Hubei adapt, highlighting the development of competitive industries in Hubei Province, through cross-border electricity Suppliers for development and speed up the adjustment of product distribution companies, in order to promote innovation and equipment manufacturing industry, represented by the second, the computer and other modern service industry in Hubei Province is rich in order to achieve the purpose of optimizing the structure.

\section{Conclusion}

In the context of economic globalization, cross-border e-commerce for the development of a country's foreign trade has a vital role. Cross-border e-commerce is an important way and means to facilitate trade development mode change, it brings innovative sales channels and business forms, breaking the constraints of traditional business marketing model suffered, help enterprises to explore and use a variety of marketing channels, create new economic and trade growth. This paper studies the status quo of cross-border e-commerce, characteristics and trends, focuses on cross-border e-commerce and trade growth of the interactive development of relations and cross-border e-commerce in China is discussed the problems in the development process, and finally for the problem put forward practical suggestions.

\section{Acknowledgements}

Proj: Department of Education Humanities and Social Sciences of Hubei Provincial Project No. 15Q220

\section{REFERENCE:}

[1] Brookes H, Martin W E, Zaki W. The Shocking Economic Effect of B2B [M]. Goldman, Sachs \& Co. Global Economics, February 3, 2000.

[2] Nuray T. The Impact of E-Commerce on International Trade and Employment[J]. Procedia Social And Behavioral Sciences, 2011(24) : 745-753.

[3] Li Xi. Cisco System, Inc. The Study Report of E-Commerce and Economic Growth, 2002(11). 
[4] Ma Weilong. The Trade Commission of European Union. The Study Report of E-Commerce and Economic Growth,2002(11) 